Todd Cleveland

Dr T Cleveland, College

of Arts and Sciences,

University of Arkansas,

Fayetteville, AR, United

States of America; Email:

tcclevel@uark.edu

DOI: http://dx.doi.

org/10.18820/24150479/

aa50i2.7

ISSN:0587-2405

e-ISSN: 2415-0479

Acta Academica - 2018 50(2):

136-138

(c) Creative Commons With Attribution (CC-BY)
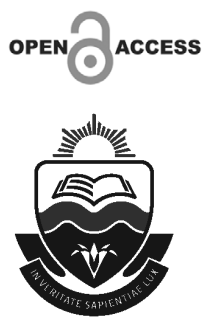

Book review

\section{Football and \\ colonialism: body and popular culture in \\ urban Mozambique}

\section{By Nuno Domingos. Athens, $\mathrm{OH}$ : University of Ohio Press, 2017.}

Nuno Domingos's Football and Colonialism examines the introduction and diffusion of soccer in the former Portuguese colony of Mozambique. More than just a sports history, the book employs soccer as a prism through which to trace the shifting interactions between Africans and Europeans in Mozambique and, in particular, the colonial capital Lourenço Marques (now Maputo). Domingos deftly brings the city alive through his historical reconstruction of this dynamic space, providing the reader with a solid understanding of the steady expansion and development of this urban centre. Central to this effort is Domingos's treatment of the growth of soccer in this milieu and the ways the game both reflected the broader social changes that urbanisation was engendering and shaping this process. At the heart of the text are the African practitioners themselves, who adopted the game after being initially exposed to it by Europeans, but who gradually made it their own via a host of culturally-based practices and understandings. 
This appropriation was manifested through a series of athletic gestures through which African players' bodies expressed ways of conceiving and organising the world. These performances had a particular, locally-comprehensible logic and corresponding set of meanings. Domingos accesses a range of sources to enable him to interpret these corporal performances and make sense of their social and historical significance. The locales for these historical processes were the vibrant African suburbs, which surrounded the predominantly European centre of Lourenço Marques, known as the "cement city," but these delimitations were not impermeable. Domingos demonstrates how the game of soccer served as a bidirectional conduit, through which aspects of both African and European culture flowed. In turn, members of the resident populations of both the European city centre and African suburbs influenced one another and reciprocally shaped their respective historical trajectories. Ultimately, Domingos compellingly explores a range of social and historical dynamics through this novel study of soccer as a central component of popular culture in late colonial Mozambique, delivering both a fascinating and foundational text.

The book constitutes the culmination of a long process of research and revision. The work is rooted in Domingos's 2008 PhD dissertation (University of London), which, in turn, served as the foundation for his 2012 book Futebol e Colonialismo, published by the Institutio de Ciências Socias at the University of Lisbon, in Portuguese, Domingos's native tongue. This new English-language version, though, is more than simply a translation of the 2012 text or a reversion to the earlier dissertation. Indeed, Domingos re-organises the contents in this updated version and sharpens his arguments, rendering the book the most cogent and utile of the three versions of this study.

In order to reconstruct this ranging, multi-faceted history, Domingos accessed a multitude of primary and secondary sources. As the literature on the suburbs of Lourenço Marques is thin and scholarship on sports in Portuguese colonial Africa non-existent, in order to build the evidentiary foundation for his study Domingos fruitfully mined archives in both Mozambique and Portugal. Arguably, though, the newspaper "O Brado Africano" constituted the most crucial source in the research process. Fully established by the 1920s, the paper was one of the first African weeklies, featuring contributions in both Portuguese and Ronga, and regular pieces by Craveirinha. For Domingos's purposes, "O Brado Africano" offers unparalleled commentary and insights into daily life in the suburbs of Lourenço Marques, the epicentre of his study. Other Mozambican (and Portuguese) periodicals also proved useful, mainly due to their chronicling of the increasing importance of sport as a form of popular culture in both the colonies and metropole. Finally, Domingos conducted a series of interviews, primarily with former players, and adeptly sprinkles in the oral testimony he gathered 
throughout the narrative, illuminating many aspects of suburban life and soccer that are otherwise invisible in the written sources.

For all of this book's myriad attributes, more direct and sustained engagement with the historiography that considers the "soccer process" in colonial Africa could have enhanced Domingos's, albeit already substantial, contribution. Domingos is certainly familiar with this literature, as he periodically cites some of the key pieces within this corpus. However, an open dialogue with the analyses and conclusions of authors of relevant, contemporaneous histories in South Africa (Alegi), Zanzibar (Fair), and the French Congo (Martin) would have enabled the reader to fully assess what made the Mozambican case unique - and, similarly, what these examples may have had in common. ${ }^{1}$ Rather than simply constituting an exercise in comparative history, an engagement with these temporally parallel accounts has the potential to deepen an understanding of why Mozambicans responded to the introduction and dissemination of soccer in the particular ways they did and, conversely, explain why certain responses were absent in that context.

This (virtually solitary) concern notwithstanding, Football and Colonialism is much more than just a book about soccer. It provides a topically-welcoming point of entry into a series of important historical dynamics, including encounters between European and indigenous cultures and the ways that Africans creatively responded to colonial overrule. Domingos has crafted an accessible, wideranging history that effortlessly oscillates between colonial policy and indigenous response. The book is ideal for an upper-level undergraduate course, but will be especially appreciated by graduate students and scholars interested in Lusophone Africa, colonialism and empire, social history, sports history and popular culture, across a range of disciplines. The text's broad appeal is a reflection of Domingos's obvious comfortableness as he moves between the bodies of relevant historical, anthropological and political science literature. Ultimately, future scholars from a wide variety of fields will benefit from Domingos's rich reconstruction and analysis of daily life in the suburbs of Lourenço Marques, regardless of whether they're interested in soccer or not. Among the book's wealth of contributions, this feature may well be the one that renders Football and Colonialism so enduringly important.

1 For example, Domingos briefly cites: Phyllis M. Martin, Leisure and Society in Colonial Brazzaville (Cambridge: Cambridge University Press, 1995); Laura Fair, Pastimes and Politics: Culture, Community and Identity in Post-Abolition Urban Zanzibar, 1890-1945 (Oxford, James Currey, 2001); and Peter Alegi, Laduma!: Soccer, Politics and Society in South Africa (Natal: University of Kwazulu-Natal Press, 2004), but neither cites nor includes in his bibliography similarly relevant works, including: Laura Fair, "Kickin' It: Leisure, Politics and Football in Colonial Zanzibar, 1900s-1950s, Africa 67:2 (1997): 224-51; and Peter Alegi, African Soccerscapes: How a Continent Changed the World's Game (Athens, Ohio: Ohio University Press, 2010). 